\title{
PERAN PEMERINTAH KOTA SURABAYA DALAM PENGATURAN TRANSPORTASI PUBLIK KOTA SURABAYA: STUDI PERKOTAAN PROGRAM "SUROBOYO BUS"
}

\author{
M. Bayu Winaryo ${ }^{1}$, Ucu Martanto ${ }^{2}$ \\ ${ }^{1}$ Departemen Politik, Fakultas Ilmu Sosial dan Ilmu Politik, Universitas Airlangga \\ bayuwinaryo27@gmail.com \\ ${ }^{2}$ Departemen Politik, Fakultas Ilmu Sosial dan Ilmu Politik, Universitas Airlangga \\ ucu.martanto@fisip.unair.ac.id
}

\begin{abstract}
The research focuses on the role of government institutions related to regulating public transportation in the city of Surabaya. Transportation is one sector which influences the economic growth of a city, the potential to be utilized as a commodity used in obtaining sources of power by some parties. Because in the practice of management, how a ruling regime is able to regulate, control and determine the direction of policy that will influence various efforts taken by the government to encourage economic growth from the region so as to be able to "turn on industrial machinery in its territory" and create new economic growth centers. Suroboyo Bus is also a manifestation of ongoing democracy in the city of Surabaya. In this study, we will explain several problems, first discussing the institutions involved in the process of forming a political decision related to the management of Suroboyo Bus, secondly about the interests involved in the political decision, the three relations that will emerge during the process. In this study it is known that the mayor is the institution that most determines the direction of policy that will be taken in the transportation sector in the city of Surabaya.
\end{abstract}

Keywords: Politics of transportation, urban regime theory, public policy, political decisions.

\section{PENDAHULUAN}

Dalam pertumbuhan suatu kota tidak terlepas dari peran pemerintah serta kepentingankepentingan pihak terkait yang ikut mempengaruhinya. Dalam pertumbuhan suatu kota, Pemerintah merupakan salah satu pemilik kekuasaan yang pada akhirnya akan membentuk suatu rezim yang mampu mempengaruhi berbagai keputusan politik dan arah kebijakan yang akan diambil oleh pihak Pemerintah Kota untuk mendorong pertumbuhan ekonomi dengan menghidupkan mesin-mesin industri di wilayahnya agar dapat tercipta pusat-pusat pertumbuhan ekonomi baru, yang akhirnya mampu memicu perputaran ekonomi yang lebih cepat serta menjadikan pendapatan dari masyarakat semakin meningkat. Suatu rezim ikut mengambil peran dalam mempengaruhi arah kebijakan yang akan diambil melalui sumber-sumber kekuasaan yang mereka miliki. Salah satu indikator yang dapat dilihat terkait dengan pertumbuhan suatu kota adalah dari bagaimana mereka mampu menggerakkan mesin-mesin industri yang ada di wilayahnya sehingga dapat membuka lahan bagi para pemilik modal untuk melakukan investasi dan mendorong pertumbuhan yang semakin pesat pada wilayah nya. Transportasi merupakan salah satu komoditas baru yang dapat dikelola dalam memperoleh sumber-sumber kekuasaan serta keuntungan dari segi ekonomi sehingga mampu mendatangkan pendapatan serta membuka peluang baru bagi para pemilik modal untuk melakukan investasi.

Pertumbuhan Kendaraan yang mencapai 7,03\% setiap tahunnya, menyebabkan berbagai permasalahan di bidang transportasi. Tingginya pertumbuhan jumlah kendaraan yang tidak mampu lagi 
diimbangi oleh ketersediaan lebar jalan menyebabkan kemacetan pada sebagian besar jalan di Surabaya. Selain kemacetan, permasalahan lain seperti tingginya polusi yang ditimbulkan serta tingginya angka kecelakaan yang terjadi menimbulkan permasalah-permasalahan yang harus dapat diselesaikan oleh pihak pemerintah dibidang transportasi agar tidak semakin berlarut-larut dan menimbulkan permasalahan-permasalahan baru dimasa yang akan datang. Transportasi publik merupakan salah satu alternatif yang diharapkan mampu mengurangi berbagai permasalahan tersebut. Karena pada dasarnya transportasi publik merupakan salah satu hal yang penting untuk diperhatikan terutama dalam mendukung mobilitas masyarakat Surabaya yang sangat tinggi. Namun, pada kenyataannya permasalahan terkait transportasi publik yang dimiliki oleh pemerintah Kota Surabaya juga belum memadai untuk dijadikan sebagai alternatif tersebut. permasalahan terkait armada, infrastruktur, sarana prasarana, regulasi, dan operasi masih perlu dilakukan berbagai pembenahan diberbagai sektor. Diharapkan solusi ini mampu menarik minat masyarakat untuk mengurangi kemacetan, polusi serta kecelakaan yang sering terjadi pada pengguna kendaraan pribadi. Untuk itu diperlukan kehadiran moda transportasi yang nyaman, aman serta mampu mengakomodir dan menarik minat masyarakat agar beralih dari kendaraan pribadi ke transportasi massal. Berbagai alternatif sudah pernah ingin dihadirkan oleh Pemerintah Kota Surabaya namun pada pelaksanaannya memang mengalami berbagai kendala. Salah satu contohnya adalah kegagalan Pemerintah Kota Surabaya dalam Menghadirkan Trem atau MRT yang mana keduanya belum mampu terealisasi hingga saat ini.

Suroboyo Bus sendiri hadir di tengah harapan masyarakat Kota Surabaya yang mengharapkan kehadiran moda transportasi yang mampu menjawab permasalahanpermasalahan transportasi yang selama ini dihadapi, di tengah kegagalan pemerintah Kota Surabaya dalam menghadirkan MRT maupun Trem yang selama ini digadang-gadang mampu menjadi salah satu solusi mengatasi berbagai permasalahan transportasi yang dihadapi Kota Surabaya. Dalam kehadirannya sendiri, selain banyak menimbulkan keuntungan, namun juga menimbulkan beberapa permasalahan baru yang harus diselesaikan oleh Pemerintah Kota Surabaya. Salah satu masalah yang bisa dilihat dari kehadiran Suroboyo Bus ini adalah tidak didukungnya infrastruktur yang memadai mengingat tidak disediakannya jalur khusus bagi bus ini yang mana dengan dimensi bus yang cukup besar bagi sebagian besar jalanan yang ada di kota Surabaya ini yang di awal kehadirannya diharapkan mampu mengurangi kemacetan yang ada, justru menimbulkan penumpukan kendaraan ketika bus ini lewat pada beberapa titik terutama pada jalan-jalan sempit dan persimpangan, dan hal tersebut sangat terlihat ketika di persimpangan dan posisi bus akan berbelok yang mana membutuhkan waktu yang lumayan lama mengingat ukuran bus yang panjang sehingga terjadi penumpukan kendaraan di belakangnya.. Selain itu tidak adanya untuk halte dari bus ini juga dapat dikatakan belum layak mengingat masih ada beberapa halte yang belum memiliki bangunan fisik yang mana tidak ada tempat duduk serta tempat berteduh bagi calon penumpang yang ingin menggunakan moda transportasi ini.

Permasalahan lain yang timbul adalah terkait dengan kebijakan pembayaran yang menggunakan sampah botol plastik dan tidak menerima pembayaran menggunakan uang. Kebijakan tersebut bagi 
sebagian calon penumpang menjadi alasan bagi mereka untuk tidak menggunakan moda transportasi ini mengingat mereka harus mengumpulkan sampah botol untuk kemudian disetorkan ke bank sampah yang sudah disediakan dan ditukar menjadi poin yang selanjutnya digunakan untuk membayar atau bahkan mereka harus membawa sampah botol ketika ingin naik bus. Hal tersebut sangat merepotkan bagi sebagian orang, meskipun di pihak lain ada sebagian masyarakat yang juga lebih senang atas kebijakan tersebut mengingat mereka tidak perlu mengeluarkan sepeser uang pun untuk bisa menikmati bus ini. Namun, jika dilihat dari latar belakang dihadirkan bus ini yang ingin menarik minat pengguna kendaraan pribadi agar mau beralih ke kendaraan umum yang sebagian besar dapat dilihat adalah kaum pekerja yang membutuhkan moda transportasi yang simple dan tidak ribet maka metode pembayaran ini perlu dikaji ulang agar semua kalangan mampu merasakan manfaat atas hadirnya Suroboyo Bus ini dan meningkatkan aksestabilitas bagi para calon penumpangnya. Kurang Fleksibelnya kebijakan terkait metode pembayaran yang ditentukan oleh pihak Pemerintah selaku pembuat regulasi menyebabkan rendahnya tingkat aksestabilitas pada moda transportasi ini dinilai sangat rendah, yang mana hal tersebut justru membuat tujuan diadakannya suatu moda transportasi menjadi tidak tercapai, dikarenakan dari segi aksestabilitas yang dimiliki masyarakat selaku pengguna nya menjadi sangat rendah. Lalu untuk apa diadakan suatu moda transportasi publik.

\section{Urban Regime Theory (Teori Rezim Perkotaan)}

Politik perkotaan erat kaitannya dengan bagaimana suatu kota mampu mengelola kewenangan serta kekuasaan politik yang dimiliki. Hal tersebut berkaitan dengan fragmentasi dari suatu kewenangan yang telah terbangun dan bagaimana suatu kota mampu menyelesaikan berbagai permasalahan yang dihadapinya serta bagaimana suatu pemerintahan dapat berjalan berdasarkan kekuasaan dimiliki, sehingga birokrasi dapat berjalan sesuai fungsinya dalam suatu pemerintahan. Karena teori ini berpendapat bahwa suatu organisasi politik mampu membentuk kontrol popular yang menjadikan pemerintah menjadi kurang responsif atas permasalah sosial ekonomi yang dihadapi. Karena dalam menentukan arah keputusan politik yang diambil dalam suatu pemerintahan tentu tidak akan lepas dari pengaruh dari pemilik kepentingan terkait.

Berbicara mengenai rezim yang terlibat dalam pertumbuhan suatu kota, tidak hanya berkaitan dengan suatu perubahan serta pergeseran dari siapa yang berkuasa melainkan lebih melihat kepada perubahan dan pergeseran dari suatu objek yang dikuasai itu sendiri. Karena disini yang lebih dilihat adalah lahan yang dikelola sebagai suatu komoditas yang dapat digunakan untuk memperoleh sumber kekuasaan serta keuntungan dari segi ekonomi. Karena pada prakteknya apabila suatu kelompok elite digantikan oleh kelompok elite lain ditengah jalan dari suatu proyek pertumbuhan kota itu tadi, kelompok elite baru sebagai penerus/pengganti dari rezim sebelumnya tidak dapat disalahkan dan tidak dapat merubah konsensus atau kesepakatan yang sudah ada sebelumnya.Karena dalam Pertumbuhan suatu kota, Suatu konsensus akan lebih kuat dibandingkan kebijakan yang akan dibuat mengingat bahwa konsensus adalah merupakan salah satu kunci utama dalam pertumbuhan suatu kota. 
Pada intinya teori ini menekankan terjadinya suatu kerjasama atau koalisi yang terjalin antara pemerintah sebagai pemilik sumber-sumber kekuasaan tertinggi dalam suatu wilayah dan pemilik modal sebagai elite ekonomi yang membantu dari segi modal. Diharapkan keduanya mampu menjalin suatu kerjasama yang baik agar mampu mengembangkan suatu wilayah. maupun kota menjadi lebih maju. Karena konsensus yang terjalin antara keduanya akan mempengaruhi arak kebijakan yang diambil oleh pihak Pemerintah sebagai pembuat regulasi dalam suatu wilayah perkotaan yang mana akan berdampak pada pertumbuhan dari suatu wilayah atau kota tersebut dan kesejahteraan suatu masyarakat tergantung pada kepentingan yang dimiliki oleh suatu rezim yang berkuasa, apakah kepentingan tersebut kan menguntungkan atau tidak bagi masyarakat itu sendiri.

Peran yang dimiliki oleh pemerintah sebagai elite yang pemegang kekuasaan dari suatu wilayah akan membentuk suatu rezim yang akan mempengaruhi berbagai upaya yang diambil oleh pihak pemerintah dalam mendorong pertumbuhan ekonomi di wilayahnya dan diharapkan mampu menghidupkan mesin-mesin industri yang ada agar tercipta pusat-pusat pertumbuhan ekonomi baru, dan memicu perputaran ekonomi yang lebih cepat serta menjadikan pendapatan dari masyarakat semakin meningkat. Karena pertumbuhan suatu kota dapat dilihat dari pergerakan mesin-mesin industri yang ada pada wilayahnya. Terkait transportasi, adalah bagaimana pemerintah mampu memanfaatkan sektor ini sebagai komoditi dalam memperoleh kekuasaan serta keuntungan dalam segi ekonomi serta tetap mampu memberikan pelayan yang baik bagi masyarakat, sehingga dalam pengelolaannya adalah bagaimana suatu rezim yang berkuasa dengan berbagai kepentingan yang dimiliki mempengaruhi arah keputusan politik yang diambil dalam upaya pengelolaan transportasi publik ini.

\section{Lembaga yang Terlibat dalam Proses Pembuatan Kebijakan Program Suroboyo Bus}

Suroboyo Bus hadir sebagai salah satu bagian dari agenda pengembangan dan pembangunan wilayah yang memiliki fokus pada pengadaan sistem transportasi serta infrastruktur layak bagi masyarakat Kota Surabaya sebagai upaya untuk meningkatkan ekonomi serta kualitas pelayanan publik yang dilakukan oleh Pemerintah Kota Surabaya serta menjalankan amanat UU No. 22 Tahun 2009. Dalam pelaksanaannya program ini tidak terlepas dari berbagai kepentingan yang menentukan arah keputusan politik yang diambil oleh Pemerintah Kota Surabaya. Dalam suatu program, pastilah terdapat tujuan awal yang ingin dicapai oleh pihak inisiator sebagai pencetus ide terkait suatu program, begitu juga dengan Program Suroboyo bus ini.

Pada awal dicetuskannya ide Suroboyo Bus ini hingga proses perencanaan dan penerapan tidak terlepas dari berbagai kepentingan yang ingin dicapai baik oleh pencetus maupun pengelola serta pihakpihak lain yang terlibat di dalamnya. Berkaitan dengan Program Suroboyo Bus ini terdapat lembaga eksekutif dan legislatif yang ikut terlibat dalam perencanaan maupun pengelolaannya. Lembaga eksekutif sebagai inisiator serta eksekutor atas setiap program yang dilakukan dalam suatu pemerintahan dan legislatif sebagai pihak yang mengawasi dan menyetujui setiap perencanaan program yang sudah dibuat.. Dalam proses penyusunan Kebijakan Program Suroboyo Bus ini, lembaga eksekutif yang terlibat dalam penyusunan Kebijakan Program Suroboyo Bus terdiri Walikota, Dinas Perhubungan 
(DISHUB), Dinas Kebersihan Dan Ruang Terbuka Hijau (DKRTH) dan BAPPEKO Kota Surabaya. Sedangkan lembaga legislatif yang terlibat adalah DPRD Kota Surabaya yang berasal dari Komisi B dan Komisi C.

Dalam Proses penyusunan kebijakan Program Suroboyo Bus, BAPPEKO memiliki peran untuk menyusun Rancangan draf anggaran yang diperlukan dalam Program Suroboyo Bus, yang nantinya draf tersebut menjadi patokan dalam penyusunan anggaran kebijakan Program Suroboyo Bus. Dalam pelaksanaan pengelolaan Dinas Perhubungan (DISHUB) Kota Surabaya pada Program Suroboyo Bus ini secara garis besar akan lebih ke arah teknis dalam pengadaan, pengoperasian dan perawatan dari armada Suroboyo Bus itu sendiri. Selain itu alasan dilibatkannya Dinas Perhubungan adalah karena DISHUB merupakan stakeholder yang ada di dalam struktur Pemerintah Kota yang memiliki akses pada anggaran terkait Transportasi yang ada di kota Surabaya ini. Sedangkan untuk Dinas Kebersihan Dan Ruang Terbuka Hijau (DKRTH) Kota Surabaya berperan dalam pengelolaan sampah plastik yang digunakan dalam pembayaran pengguna moda transportasi ini. Sementara itu peran sebagai inisiator lebih banyak dilakukan oleh Walikota Surabaya selaku pemegang kekuasaan tertinggi dalam struktural Pemerintah Kota Surabaya. Untuk lembaga legislatif sendiri terdiri dari Anggota Komisi B DPRD Surabaya terkait kebijakan retribusi dari Program Suroboyo Bus dan Komisi C DPRD Surabaya yang menangani permasalahan terkait dengan kebijakan moda transportasi. Perkembangannya, karena DPRD memiliki 3 fungsi, fungsi legislasi, anggaran dan pengawasan. Dan dalam hal adanya inovasi program Suroboyo Bus ini, DPRD memang memainkan peran sebagaimana fungsinya tersebut. DPRD Kota Surabaya di sini berperan sebagai regulator dalam proses penyusunan Kebijakan Program Suroboyo Bus ini. Yang mana secara teknis tugas dari DPRD kota Surabaya ini dibagi lagi menjadi 2 yaitu: Pertama, menangani terkait dengan kebijakan Retribusi Suroboyo Bus, Tugas ini dimiliki oleh Komisi B DPRD Kota Surabaya yang ikut menyusun dan mengawasi segala jenis kebijakan retribusi yang akan dilakukan pada Program Suroboyo Bus. Kedua, menangani terkait dengan kebijakan Moda Transportasi Suroboyo Bus, Tugas ini dimiliki oleh Komisi C DPRD Kota Surabaya yang ikut menentukan dan mengawasi moda transportasi yang digunakan pada Program Suroboyo Bus.

DPRD yang memiliki wewenang sebagai regulator pada sistem pemerintahan, berhak memberikan persetujuan maupun penolakan terhadap rancangan program yang diajukan oleh pihak pemerintah. Terlebih apabila tidak dilibatkannya pihak DPRD dalam perencanaan suatu program maka kemungkinan untuk program tersebut dapat disetujui dan terealisasi menjadi sangat kecil mengingat tugas dari DPRD yang berperan sebagai regulator atas kinerja dari pihak eksekutif yang memiliki hak untuk menolak rancangan program yang diajukan oleh lembaga eksekutif. Namun jika melihat jumlah kursi yang dimiliki oleh PDI-perjuangan yang notabene merupakan partai pengusung Walikota selaku lembaga eksekutif tertinggi dalam struktur Pemerintah Kota Surabaya, justru menjadikan struktur DPRD Kota Surabaya menjadi salah satu sumber kekuasaan yang dimiliki oleh Walikota dalam merealisasikan setiap program yang lembaga eksekutif rencanakan. Peran lembaga sebagai eksekutif sebagai inisiator akan semakin mudah untuk mendapat persetujuan dari pihak legislatif mengingat adanya sumber 
kekuasaan yang dimiliki pihak eksekutif dalam hal ini walikota terhadap partai pengusungnya yang memiliki dominasi kursi dalam lembaga legislatif. Dengan kursi yang dimiliki PDI-P dalam struktur DPRD Kota Surabaya sebanyak 15 kursi tersebut sudah cukup mendominasi arah keputusan politik yang akan diambil oleh DPRD Kota Surabaya terutama dalam menyukseskan programprogram yang diajukan oleh rekanan partainya, Walikota yang memiliki wewenang sebagai inisiator bagi setiap program yang akan diterapkan di Surabaya.

Di sisi lain, dalam pengelolaan Suroboyo Bus ini, sama sekali tidak melibatkan DAMRI. Hal tersebut mengingat bentuk DAMRI yang saat ini adalah Perusahaan Umum "PERUM" yang mengharuskan lembaga ini mencari keuntungan untuk perusahaannya. Sementara itu, Pemerintah Kota Surabaya menginginkan hadirnya Suroboyo Bus ini lebih mengutamakan pelayanan serta edukasi bagi seluruh masyarakat. Apabila dalam pengelolaannya melibatkan Perum DAMRI, dikhawatirkan keputusan pembayaran 100\% menggunakan sampah botol plastik tidak bisa sepenuhnya diterapkan sesuai harapan awal perencanaan Program Suroboyo Bus ini, sehingga pada pelaksanaannya, Suroboyo Bus yang tidak memiliki Badan Hukum yang menaungi layaknya Bus TransJakarta tidak bisa menggunakan plat berwarna kuning meskipun statusnya sebagai transportasi publik atau angkutan umum.

\section{Analisis Kebijakan Pemerintah Kota Surabaya terkait Program Suroboyo Bus}

Berkaitan dengan implementasi dari kebijakan Suroboyo Bus ini, dapat menunjukkan bahwa terdapat kepedulian Pemerintah Kota Surabaya di sektor transportasi yang selama ini tidak banyak mendapat perhatian oleh pihak Pemerintah Kota Surabaya. Kebijakan yang dibuat oleh Pemerintah Kota Surabaya terkait Program Suroboyo Bus, merupakan usaha Pemerintah dalam mengatasi permasalahan transportasi yang selama ini dihadapi terkait kemacetan, polusi serta tingginya angka kecelakaan yang terjadi. Suroboyo Bus hadir sebagai alternatif baru yang hadir di tengah kegagalan Pemerintah Kota Surabaya dalam menghadirkan Trem maupun MRT yang selama ini digadang-gadang akan segera hadir di Surabaya. Selain itu, Suroboyo Bus diharapkan mampu memberikan solusi serta jaminan dan kepastian menanggapi persoalan-persoalan transportasi yang terjadi ditengah masyarakat. Suroboyo Bus juga diharapkan menjadi wujud demokrasi yang sedang berjalan di Kota Surabaya. Di mana dapat menunjukkan bagaimana peran negara turut serta hadir di tengah-tengah masyarakat sipil, di mana masyarakat juga dapat mempengaruhi negara dalam wujud pembentukan kebijakan-kebijakan yang diterapkan. Hadirnya Suroboyo Bus sebagai jawaban atas permasalahan transportasi yang dihadapi masyarakat Kota Surabaya merupakan wujud dari hadirnya negara terhadap masyarakat yang dipimpin.

Suroboyo Bus yang pada awal diluncurkannya hanya berjumlah 10 unit, yang kemudian pada tanggal 4 Januari 2019 bertempat di taman Surya, menambah jumlah armada sebanyak 10 unit lagi, sehingga secara keseluruhan jumlah Suroboyo Bus sejak tanggal 4 Januari 2019 menjadi 20 unit. Menunjukkan adanya keseriusan yang dilakukan oleh Pemerintah Kota Surabaya dalam menjalankan program ini. Penambahan unit ini diketahui juga bertujuan untuk meningkatkan pelayanan yang lebih 
baik bagi masyarakat Kota Surabaya. Selain itu dapat dilihat bahwa Program Suroboyo Bus merupakan bentuk tanggung jawab Pemkot Surabaya menciptakan transportasi yang aman bagi seluruh masyarakat Kota Surabaya. Program Suroboyo Bus, merupakan usaha dalam memfasilitasi aspirasi dan kebutuhan masyarakat pada sektor transportasi massal, dan mampu berpihak pada masyarakat serta memberikan jaminan atau kepastian menanggapi persoalanpersoalan yang terjadi di tengah masyarakat ikut mewarnai pemerintahan demokrasi saat ini.

Kebijakan Program Suroboyo Bus menjadi wujud intervensi pemerintah yang dilakukan demi kepentingan masyarakat untuk menyelesaikan permasalahan-permasalahan di bidang transportasi. Berdasarkan berbagai temuan di lapangan, secara normatif fokus dari pengadaan Suroboyo Bus ini dibagi menjadi dua. Pertama, Sebagai upaya Pemerintah Kota Surabaya dalam mengatasi masalah kemacetan yang terjadi di kota Surabaya. Dalam implementasinya, Pemerintah Kota Surabaya telah menyediakan alternatif moda transportasi baru yang mampu mengakomodir kebutuhan transportasi bagi masyarakat kota Surabaya yang aman, nyaman dan terjangkau. Dengan harapan untuk menarik minat masyarakat kota Surabaya agar mau beralih dari penggunaan kendaraan pribadi ke angkutan umum. Kedua, Sebagai upaya yang dilakukan oleh pemerintah kota Surabaya dalam memberikan edukasi terhadap masyarakat terkait lingkungan hidup serta pengelolaan sampah plastik yang selama ini juga menjadi salah satu permasalahan yang dihadapi oleh Pemerintah Kota Surabaya.

Di sisi lain, dipilihnya metode pembayaran menggunakan sampah botol plastik sebagaimana yang sudah diatur dalam PERWALI No. 67 tahun 2018 tentang Tentang kontribusi sampah dalam penggunaan layanan bus Surabaya. Merupakan inovasi yang belum pernah dilakukan oleh kota lain di Indonesia. Surabaya merupakan satu-satunya kota yang menerapkan metode pembayaran menggunakan sampah botol plastik sebagai alat pembayaran untuk moda transportasi yang disediakan di kotanya. Kebijakan pembayaran yang menggunakan sampah botol plastik dan tidak menerima pembayaran menggunakan uang. Kebijakan tersebut bagi sebagian calon penumpang menjadi alasan bagi mereka untuk tidak menggunakan moda transportasi ini mengingat mereka harus mengumpulkan sampah botol untuk kemudian disetorkan ke bank sampah yang sudah disediakan dan ditukar menjadi poin yang selanjutnya digunakan untuk membayar atau bahkan mereka harus membawa sampah botol ketika ingin naik bus. Hal tersebut sangat merepotkan bagi sebagian orang, meskipun di pihak lain ada sebagian masyarakat yang juga lebih senang atas kebijakan tersebut mengingat mereka tidak perlu mengeluarkan sepeser uang pun untuk bisa menikmati bus ini. Namun, jika dilihat dari latar belakang dihadirkan bus ini yang ingin menarik minat pengguna kendaraan pribadi agar mau beralih ke kendaraan umum yang sebagian besar dapat dilihat adalah kaum pekerja yang membutuhkan moda transportasi yang simpel dan tidak ribet maka metode pembayaran ini perlu dikaji ulang agar semua kalangan mampu merasakan manfaat atas hadirnya Suroboyo Bus ini dan meningkatkan aksestabilitas bagi para calon penumpangnya. Kurang fleksibelnya kebijakan terkait metode pembayaran yang ditentukan oleh pihak pemerintah selaku pembuat regulasi menyebabkan rendahnya tingkat aksestabilitas pada moda transportasi ini dinilai sangat rendah, yang mana hal tersebut justru membuat tujuan diadakannya suatu 
moda transportasi menjadi tidak tercapai, dikarenakan dari segi aksestabilitas yang dimiliki masyarakat selaku penggunanya menjadi sangat rendah. Lalu untuk apa diadakan suatu moda transportasi publik.

Di sisi lain, dalam pengelolaan Suroboyo Bus ini, sama sekali tidak melibatkan DAMRI. Hal tersebut mengingat bentuk DAMRI yang saat ini adalah Perusahaan Umum "PERUM" yang mengharuskan lembaga ini mencari keuntungan untuk perusahaannya. Disisi lain, Pemerintah Kota Surabaya menginginkan hadirnya Suroboyo Bus ini lebih mengutamakan pelayanan serta edukasi bagi seluruh masyarakat. Apabila dalam pengelolaannya melibatkan Perum DAMRI, dikhawatirkan keputusan pembayaran $100 \%$ menggunakan sampah botol plastik tidak bisa sepenuhnya diterapkan sesuai harapan awal perencanaan Program Suroboyo Bus ini. Terkait dengan pengelolaan Suroboyo Bus ada baiknya jika dibentuk suatu badan Khusus yang menangani. Mengingat kota lain di Indonesia sudah memiliki badan tersebut. Untuk menarik investor agar mau berinvestasi pada bidang transportasi. badan berupa BUMD akan lebih tepat dipilih mengingat badan ini juga masih tetap menekankan pada public service oriented sehingga masyarakat juga masih bisa mendapatkan pelayanan yang baik namun tidak menghalangi pula niat bagi para pemilik modal untuk berinvestasi.

\section{SIMPULAN}

Program Suroboyo Bus merupakan bentuk konsensus yang berhasil dilakukan oleh lembaga eksekutif dan lembaga legislatif yang ada di Kota Surabaya. Pada program Suroboyo lembaga eksekutif yang terlibat adalah Walikota, Bappeko, Dinas Perhubungan Kota Surabaya Bagian Kepala Unit Suroboyo Bus, Dinas Kebersihan dan Ruang Terbuka Hijau. Sedangkan untuk lembaga legislatif yang terlibat adalah anggota Dewan Perwakilan Rakyat Daerah Kota Surabaya dari Komisi B dan C. Walikota berperan sebagai inisiator pada program ini yang selanjutnya ditindaklanjuti oleh BAPPEKO sebagai penyusun Rancangan Anggaran yang akan digunakan serta DISHUB sebagai dinas yang berwenang pada bidang ini. DKRTH sendiri dilibatkan dalam upaya menangani sampah yang dikelola sebagai alat pembayaran bagi penumpang Suroboyo Bus. Sedangkan untuk lembaga legislatif terbagi menjadi 2 yaitu: 1. Komisi B DPRD Kota Surabaya yang bertanggung jawab menangani kebijakan terkait Retribusi Suroboyo Bus. Tugas Komisi B adalah ikut menyusun dan mengawasi segala jenis kebijakan retribusi yang akan dilakukan pada Program Suroboyo Bus. Untuk Komisi C bertugas menangani kebijakan terkait Moda Transportasi Suroboyo Bus, Tugas Komisi C DPRD Kota Surabaya adalah ikut menentukan dan mengawasi moda transportasi yang digunakan pada Program Suroboyo Bus.

Dalam pelaksanaan Program Suroboyo Bus ini dapat dikatakan sudah terjalin kesepakatan dan keduanya setuju untuk menjalankan Program ini. Atas terlaksananya program ini, membuktikan bahwa telah terjadi sebuah konsensus dalam proses perencanaan yang melibatkan Pemerintah Kota Surabaya sebagai lembaga eksekutif dan DPRD Kota Surabaya sebagai lembaga legislatif. Pada prosesnya lembaga eksekutif yang memiliki peran sebagai inisiator sudah mendapatkan persetujuan atas rancangan yang diajukan pada pihak eksekutif. Berdasarkan temuan di lapangan, Pemerintah Kota Surabaya mampu membentuk suatu rezim yang terintegrasi di bawah kekuasaan yang dimiliki oleh Walikota Surabaya dalam menggerakkan mesin-mesin industri pada bidang Transportasi di Kota Surabaya yang 
secara garis besar bertujuan untuk menyejahterakan kehidupan masyarakat Kota Surabaya serta menjalankan perputaran ekonomi yang ada di Kota Surabaya melalui pelayanan transportasi yang layak dan memadai.

\section{DAFTAR PUSTAKA}

Aminah S (2016) Penataan Transportasi Publik-Privat dan Pengembangan Aksestabilitas Masyarakat. Surabaya: Airlannga University Press. (Bibliography)

Dunn NW (2000) Pengantar Analisis Kebijakan Publik, Edisi II. Yogyakarta: Gajah Mada University Press. (Bibliography)

Mazmanian DA \& Paul AS (1983) Implementation and Public Policy. Scott Foresman and Company, USA. (Bibliography)

Samodra W (1994) Kebijakan Publik Proses dan Analisis. Jakarta: Intermedia. (Bibliography)

Surbakti R (1992) Memahami Ilmu Politik. Jakarta: Gramedia Widya Sarana. (Bibliography)

Warjio (2016) Politik Pembangunan: Paradoks, Teori, Aktor, dan Ideologi. Jakarta:

Kencana Prenamedia Group. (Bibliography)

Suzanne K (1995) Penguasa dan Kelompok Elite: Peranan Elite Penentu dalam Masyarakat Modern. Jakarta: PT. Radja Grafindo Persada. (Bibliography) 